The analysis of the inheritance of the main quantitative signs shows that in hybrids $F_{1}$ usually is observed an intermediate manifestation of them in relation to parental forms. Deviation from the average indicators of parental forms is determined primarily by the degree of dominance of hereditary factors of one of the components of hybridization.

According to the research results, the prevailing types of inheritance of the signs of productivity of recombinant materials of beets of different genetic structures have been established. The best plant genotypes with the optimal combination of productivity traits and root shape for the further selection of multi-growth sugar beet pollinators were identified.

The valuable source material of beets of hybrid origin was obtained for repeated staged saturation crossings with high-sugar donor sources and selection new genotypes of high productive multi-growth pollinators of sugar beet with improved parameters of the root shape and partial protrusion of it above the surface of the soil.

Keywords: sugar beets, fodder beets, source material, sugar-fodder hybrid, hybridization, recombinogenesis, inheritance, productivity.

\title{
СОРТОВІ ОСОБЛИВОСТІ ФОРМУВАННЯ ВРОЖАЮ ЦИБУЛІ ПОРЕЙ В УМОВАХ ЛІСОСТЕПУ УКРАЇНИ
}

Г. Я. СЛОБОДЯНИК, кандидат сільськогосподарських наук

О. І. УЛЯНИЧ, доктор сільськогосподарських наук

А. Г. ТЕРНАВСЬКИЙ, кандидат сільськогосподарських наук

Уманський національний університет садівництва

В. І. ВОЙЦЕХІВСЬКИЙ, кандидат сільськогосподарських наук

Національний університет біоресурсів і природокористування

Наведено результати оцінювання інтенсивності формування біомаси та рівня врожайності сортів циибулі порей в умовах південної частини Правобережного Лісостепу України. Як більш перспективні виділено Колумбус, Голіас, Бартек та Веста, вирощування яких забезпечує одержання 24,4-27,4 m/га якісного товарного врожаю.

Ключові слова: иибуля порей, сорт, фотосинтетичний потенціал, несправжн стебло, врожайність.

Постановка проблеми. Завдяки впровадженню сортів і гібридів, адаптованих до умов вирощування і з високим потенціалом продуктивності можливий суттєвий прогрес галузі овочівництва і подальше нарощування 
валових зборів якісної та корисної продукції. Оцінюючи нові сорти і гібриди, звертають увагу на їх відповідність умовам клімату, вимогам ринку, рівень урожайності, тривалість зберігання. Цибуля порей належить до найбільш цінних видів овочевих рослин за біохімічним складом, урожайністю, стійкістю до хвороб i пластичністю до умов вирощування [1]. Високопродуктивних вітчизняних сортів цибулі порей немає, а інтродуковані різняться за рядом морфо-біологічних особливостей та інтенсивністю росту, що і визначає загальну продуктивність.

Аналіз останніх досліджень і публікацій. На основі вивчення в різних умовах взаємодії «Генотип - середовище» і виділення зі світової колекції джерел господарсько цінних ознак створено врожайні сорти і гібриди цибулі порей 3 високою зимостійкістю, товарними i смаковими якостями, адаптивністю до різних умов вегетації [2-4]. Важливим інструментом розширення генетичної варіації культивованих видів Allium вважається міжвидова гібридизація, зокрема, між цибулею порей (Al. leek L.) та часником (Al. sativum L.) і одержання більшого товарного врожаю, ніж у вихідних форм [5]. Обираючи сорти цибулі порей варто знати, що ранньостиглі більш урожайні, залежно від умов вирощування їх вегетаційний період триває 130-150 діб. Середньостиглі сорти порею поступаються за врожайністю ранньостиглим, але перевершують за якістю. Вегетаційний період пізньостиглих сортів становить 180 діб і більше, а врожайність відповідає рівню середньостиглих [6]. Для північних регіонів рекомендовані ранньостиглі й середньостиглі сорти цибулі порей, які набуватимуть товарної стиглості до завершення вегетаційного сезону [7-8].

Для більшої прибутковості виробництва цибулі порей необхідно реалізовувати іiі ранню продукцію вже з початку липня, а також планувати конвеєрне збирання врожаю $[7,9]$. У розсадний період більш розвинені рослини цибулі порей таких сортів, як Голіас та Осінній гігант [8]. В умовах помірно-континентального клімату за біометричними параметрами несправжнього стебла виділявся сорт Колумбус, його загальний урожай був $7,0-8,8$ кг $/ \mathrm{M}^{2}[2,6]$. Згідно вимог до якості товарний урожай повинен мати вибілену частину несправжнього стебла висотою $15-20 \mathrm{~cm}[9,4]$ Інтенсивність формування несправжнього стебла цибулі порей залежить від погодних умов, тривалості світлового дня, приросту нових листків. Технічну стиглість цибулі порей визначають за діаметром несправжнього стебла, яка для болгарського сортотипу має бути не менше 8 мм, для російського - не менше 1,5 см $[2,4,6,7]$.

Комплексних досліджень агробіологічних особливостей цибулі порей у 
різних грунтово-кліматичних умовах України недостатньо, тому метою даної роботи було оцінювання закономірностей формування біомаси i рівня продуктивності іï перспективних сортів.

Методика досліджень. Впродовж 2016-2018 pр. на дослідних ділянках Уманського НУС вивчали інтенсивність росту і продуктивність таких закордонних сортів цибулі порей: Мацек (контроль), Голіас, Колумбус, Веста, Танго, Порбелла, Бартек. Висаджували 50-денну безкасетну розсаду за схемою $70 \times 10 \mathrm{~cm}$. Грунт - чорнозем опідзолений важкосуглинковий 3 умістом гумусу 2,9\%. Погодні умови під час вирощування цибулі порей характеризувались температурою вище норми та низькою вологістю повітря. В першій половині вегетації оптимальну вологість грунту підтримували краплинним зрошенням. Спостереження за ростом і розвитком рослин, розрахунки площі асиміляційної поверхні листків, фотосинтетичного потенціалу, чистої продуктивності фотосинтезу, загального і товарного врожаю виконували, дотримуючись відповідних вимог і методик досліджень, результати оцінювали дисперсійним і кореляційним аналізами $[10,11]$.

Результати досліджень. Тривалість періоду від появи сходів до стану технічної стиглості досліджуваних рослин цибулі порей в умовах Лісостепу України була переважно меншою, ніж у загальній характеристиці, представленій заявниками сортів. У болгарського сортотипу Веста, що позиціонується як ранньостиглий, збиральну стиглість відмічали через $117-$ 130 діб з менш інтенсивним розвитком рослин у 2017 р., що свідчить про низьку агрономічну стабільність даного сорту (табл. 1). Впродовж періоду досліджень раніше формування несправжнього стебла діаметром $1 \mathrm{~cm}$ відмічено для рослин сортів Голіас, Порбелла, Бартек і Танго у 2017 р. через 102-107 діб після сходів. Найповільніше формували несправжнє стебло стандартного діаметру 1,5 см сорти Мацек і Порбелла у 2018 р. - лише через 129-135 діб після появи сходів. Варто відмітити, що приріст діаметру стебла від 1,0 см до 1,5 см у сортів Мацек, Веста і Танго у середньому тривав 78 діб, а у сортів Бартек, Порбелла, Колумбус і Голіас - 11-13 діб. Найменшу середню тривалість періоду від появи сходів до технічної стиглості несправжнього стебла мали рослини порею сортів Голіас і Танго - 118120 діб.

У сортів Колумбус і Бартек даний період становив 123-124 доби. Сортам Порбелла, Веста і Мацек за середньої тривалості вегетаційного періоду 129-132 доби притаманний найменш інтенсивний розвиток рослин. 


\section{Табл. 1. Тривалість періоду від появи сходів до технічної}

стиглості досліджуваних сортів цибулі порей, діб (2016-2018 рр.)

\begin{tabular}{|c|c|c|c|c|c|c|c|c|}
\hline \multirow{3}{*}{ Сорт } & \multicolumn{4}{|c|}{$\begin{array}{c}75 \% \text { рослин } 3 \text { діаметром } \\
\text { несправжнього стебла } 1 \text { см }\end{array}$} & \multicolumn{4}{|c|}{$\begin{array}{c}75 \% \text { рослин з діаметром } \\
\text { несправжнього стебла } 1,5 \text { см }\end{array}$} \\
\hline & \multicolumn{8}{|c|}{ Рік досліджень } \\
\hline & 2016 & 2017 & 2018 & $\begin{array}{c}\text { середнє за } \\
\text { три роки }\end{array}$ & 2016 & 2017 & 2018 & $\begin{array}{c}\text { середнє за } \\
\text { три роки }\end{array}$ \\
\hline $\begin{array}{l}\text { Мацек } \\
\text { (контроль) }\end{array}$ & 127 & 124 & 120 & 124 & 136 & 132 & 129 & 132 \\
\hline Голіас & 104 & 102 & 113 & 106 & 112 & 115 & 127 & 118 \\
\hline Колумбус & 110 & 109 & 114 & 111 & 123 & 120 & 125 & 123 \\
\hline Веста & 117 & 130 & 122 & 123 & 123 & 136 & 130 & 130 \\
\hline Танго & 118 & 107 & 111 & 112 & 125 & 115 & 120 & 120 \\
\hline Порбелла & 119 & 105 & 123 & 116 & 133 & 118 & 135 & 129 \\
\hline Бартек & 117 & 106 & 115 & 113 & 127 & 120 & 125 & 124 \\
\hline
\end{tabular}

Важливою умовою високої врожайності сільськогосподарських культур $€$ розвинений листковий апарат, який максимально тривалий час знаходиться в активному стані. Отримані показники фотосинтетичного потенціалу насаджень цибулі порей вказують на аналогічну 3 площею листкової поверхні закономірність і у середньому за період з 20 травня до 10 жовтня найбільші значення фотосинтетичного потенціалу відмічено у рослин сортів Голіас і Колумбус- 1,10-1,31 млн. м²хдіб/га, що в 1,5-1,8 рази більше контролю (рис. 1). Середня площа листкової поверхні даних сортів максимальна і становила 15,45-18,52 тис.м²/га. Площа листків сортів Веста, Танго і Бартек станом на 10 жовтня перевищувала варіант контролю на 1,022,23 тис.м ${ }^{2} /$ га, тому істотно вищий і фотосинтетичний потенціал - на 0,060,16 млн. м $^{2} \times$ днів/га.

Не менш важливим показником є чиста продуктивність фотосинтезу, яка відображає кількість утвореної сухої біомаси культури впродовж доби 3 розрахунку на $1 \mathrm{~m}^{2}$ площі листків. За низького рівня загальної врожайності 26 т/га і найменшої асиміляційної поверхні листків у сорту Мацек чиста

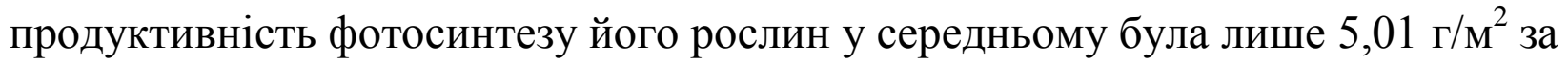
добу (рис.).

Найвищою чистою продуктивністю фотосинтезу характеризувався сорт Веста - 5,96 г/м² за добу, коли за площі листків 11,45 тис. м²/га сформовано загальний врожай 33,6 т/га. Аналогічну закономірність відмічено для сортів Танго i Бартек, чиста продуктивність фотосинтезу яких була 5,695,74 г/м²/добу за площі листків та загального врожаю 12,06-12,66 тис. м²/га 
та 25,8 т/га і 48,5 т/га відповідно. Відносно низький рівень чистої продуктивності фотосинтезу мав сорт Порбелла - 5,36 г/м²/добу. Сорти Голіас і Колумбус внаслідок досить розвиненої листкової поверхні формували загальний врожай 40,8-46,2 т/га за чистої продуктивності фотосинтезу 5,70-5,73 г/ $\mathrm{m}^{2} /$ добу, що істотно вище контролю.

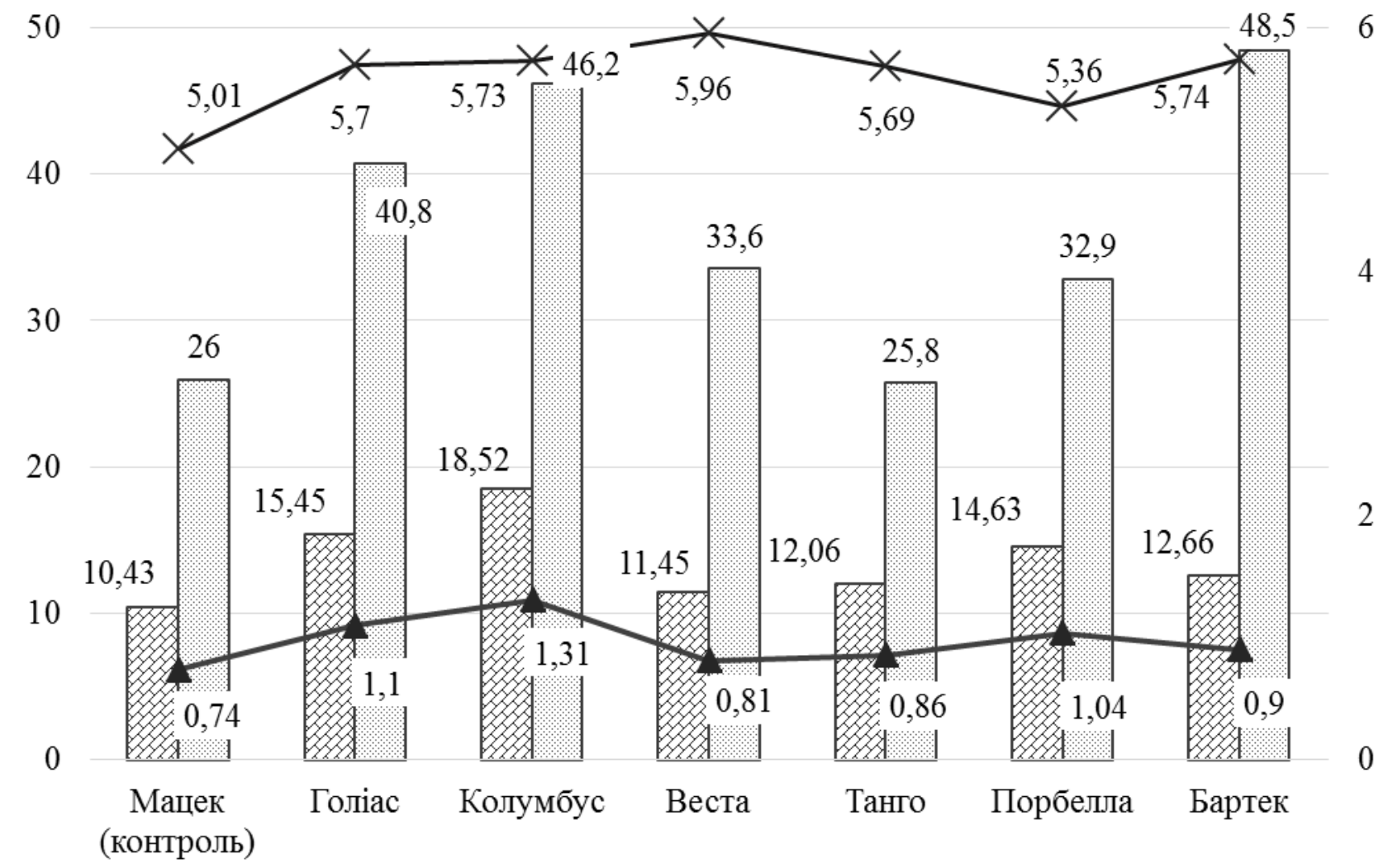

М必Площа листкової поверхні, тис. м кв./га

ФП, млн.м кв. хдіб/га

๘агальний врожай, т/га

* ЧПФ, г/м кв. за добу

\begin{tabular}{|c|l|c|c|c|}
\hline \multirow{1}{*}{$H I P_{05}$} & \multicolumn{1}{|c|}{ Показник } & 2016 рік & 2017 рік & 2018 рік \\
\cline { 2 - 5 } & $\begin{array}{l}\text { Площа листкової поверхні станом на } \\
10 . \text { Х, тис. м }{ }^{2} / \text { га }\end{array}$ & 1,1 & 2,1 & 1,6 \\
\cline { 2 - 5 } & $\begin{array}{l}\text { Фотосинтетичний потенціал (період } \\
\text { 3 20.V до 10. Х), млн.м²×діб/га (ФП) }\end{array}$ & 0,05 & 0,06 & 0,09 \\
\cline { 2 - 5 } & $\begin{array}{l}\text { Чиста продуктивність фотосинтезу, } \\
\text { г/м² за добу (ЧПФ) }\end{array}$ & 0,21 & 0,35 & 0,31 \\
\cline { 2 - 5 } & Загальна врожайність, т/га & 1,71 & 2,86 & 2,86 \\
\hline
\end{tabular}

Рис. Показники асиміляційної активності рослин та загальна врожайність сортів цибулі порей (т/га), середнє за 2016-2018 рр.

За даними кореляційного аналізу у варіанті контролю встановлено сильну пряму залежність між асиміляційною площею листків і фотосинтетичним потенціалом - коефіцієнт кореляції становив $\mathrm{r}=0,99-0,004$, 
рівняння регресії: $\mathrm{y}=0,071 \mathrm{x}+0,005$. Показники чистої продуктивності фотосинтезу мають середній зв'язок з площею листків $-\mathrm{r}=0,45 \pm 0,21 ; \mathrm{y}=$ $0,053 \mathrm{x}+4,81$ та загальною врожайністю $-\mathrm{r}=0,38 \pm 0,22, \mathrm{y}=0,014 \mathrm{x}+5,11$. Коефіцієнт кореляції між даними фотосинтетичного потенціалу і чистої продуктивності фотосинтезу та між загальною врожайністю і площею листків рослин цибулі порей сорту Мацек також вказує на середню їх залежність $-\mathrm{r}=0,46 \pm 0,21 ; \mathrm{y}=0,278 \mathrm{x}+0,61$ та $\mathrm{r}=0,65 \pm 0,17 ; \mathrm{y}=0,195 \mathrm{x}+6,633$ відповідно. Рівняння регресії залежності площі асиміляційної поверхні листків (у) від фотосинтетичного потенціалу $\left(\mathrm{x}_{1}\right)$ і чистої продуктивності фотосинтезу $\left(\mathrm{x}_{2}\right)$ має такий вигляд: $\mathrm{y}=0,32+14,19 \mathrm{x}_{1}-0,07 \mathrm{x}_{2}$.

Перспективність сортів цибулі порей визначається їх товарною масою і врожайністю. Згідно одержаних результатів найменша товарна маса несправжнього стебла у сортів Мацек і Танго - 108-112 г (табл. 2).

Табл. 2. Товарна маса і врожайність сортів цибулі порей, 2016-2018 рp.

\begin{tabular}{|c|c|c|c|c|c|c|c|}
\hline \multirow{3}{*}{ Сорт } & \multirow{3}{*}{$\begin{array}{c}\text { Середня } \\
\text { за три } \\
\text { роки } \\
\text { товарна } \\
\text { маса, } \\
\text { г/рослину }\end{array}$} & \multicolumn{5}{|c|}{ Урожайність, т/га } & \multirow{3}{*}{$\begin{array}{l}\text { Коеф } \\
\text { стаб. } \\
\text { Левіса }\end{array}$} \\
\hline & & \multicolumn{3}{|c|}{ Рік досліджень } & \multirow{2}{*}{$\begin{array}{c}\text { Середня } \\
\text { за три } \\
\text { роки }\end{array}$} & \multirow{2}{*}{$\begin{array}{c} \pm д о ~ \\
\text { контро } \\
\text { лю }\end{array}$} & \\
\hline & & 2016 & 2017 & 2018 & & & \\
\hline $\begin{array}{l}\text { Мацек } \\
\text { (контроль) }\end{array}$ & 108 & 12,3 & 16,6 & 17,3 & 15,4 & - & 1,4 \\
\hline Голіас & 174 & 14,1 & 25,6 & 35,0 & 24,9 & 9,5 & 2,5 \\
\hline Колумбус & 190 & 17,4 & 28,3 & 36,6 & 27,4 & 12,0 & 2,1 \\
\hline Веста & 178 & 20,4 & 24,0 & 31,9 & 25,4 & 10,0 & 1,6 \\
\hline Танго & 112 & 12,9 & 16,6 & 18,4 & 16,0 & 0,6 & 1,4 \\
\hline Порбелла & 138 & 18,6 & 20,0 & 20,7 & 19,8 & 4,4 & 1,1 \\
\hline Бартек & 171 & 13,9 & 25,7 & 33,6 & 24,4 & 9,0 & 2,4 \\
\hline$H_{05}$ & - & 1,4 & 1,7 & 2,9 & - & \\
\hline $\begin{array}{l}\text { Коефіиієнт } \\
\text { варіювання, Vо }\end{array}$ & - & 19,5 & 20,2 & 29,5 & 23,1 & \multicolumn{2}{|c|}{-} \\
\hline
\end{tabular}

Надалі зі збільшенням товарної маси досліджувані сорти ранжуються у такому порядку: Порбелла, Бартек, Голіас, Веста і Колумбус. Частка товарної маси становила у середньому 50\% від загальної маси у сорту Бартек, 59\% у сортів Колумбус і Мацек, 60-62\% - у сортів Голіас, Порбелла і Танго та 75\% - у Веста.

Товарна (у) і загальна врожайність (х) має сильний зв'язок, зокрема, у сорту Мацек коефіцієнт кореляції $-\mathrm{r}=0,82 \pm 0,17$ і рівняння регресії у = $0,43 \mathrm{x}+5,62$. Для даного сорту залежність товарного врожаю (у) від таких 
параметрів, як площа асиміляційної поверхні листків $\left(\mathrm{x}_{1}\right)$, загальна врожайність $\left(\mathrm{x}_{2}\right)$ і чиста продуктивність фотосинтезу $\left(\mathrm{x}_{3}\right)$ визначається наступним рівнянням регресіі: $\mathrm{y}=10,69+0,35 \mathrm{x}_{1}+0,42 \mathrm{x}_{2}-1,23 \mathrm{x}_{3}$.

Для більшості сортів притаманна низька стабільність показників товарної врожайності - коефіцієнт Левіса більше 1,2 і лише у сорту Порбелла середня - 1,1. На фоні найбільшої суми опадів за період травень-вересень 301,4 мм у 2018 р. максимальна врожайність усіх сортів, але найвищий коефіцієнт іi варіювання - 29,5\%. Найменший урожай у 2016 р., коли був значний дефіцит опадів у другій половині вегетації рослин. Неістотна різниця 3 контролем даних урожайності сорту Танго в усі роки досліджень. Найбільшою врожайністю характеризувались такі сорти цибулі порей: Колумбус - 36,6 т/га, Голіас - 35,0 і Бартек - 33,6 т/га у 2018 р. та відповідно 27,4 т/га, 24,9 і 24,4 т/га у середньому за роки досліджень. Середня товарна врожайність сорту Веста також суттєво перевищувала контроль і становила 25,4 т/га. Як менш урожайні виділено сорти Танго і Мацек - 15,4 -16,0 т/га.

Висновок. В умовах Лісостепу України інтенсивніший розвиток притаманний цибулі порей сортів Голіас, Колумбус, Танго і Бартек, їх вегетаційний період складає 118-124 доби. Найвищі показники площі листкової поверхні і чистої продуктивності фотосинтезу мають рослини сортів Колумбус, Голіас i Веста, між врожайністю і фотосинтетичним потенціалом залежність середня. Високим рівнем товарного урожаю - 24,427,4 т/га 3 надбавкою до контролю на 9,0-12,0 т/га характеризуються сорти цибулі порей Колумбус, Веста, Голіас і Бартек.

\section{Література}

1. Такаева Ш.К., Кароматов И.Д. Лекарственное растение лукпорей. Биология и интегративная медицина. 2017. № 5. С. 232-238.

2. Лубнин В.Ф., Логинова Н.А. Опыт выращивания лука порея в Иркутской области . Гавриш. 2000. № 1. С. 13-14.

3. Филюшин М.А., Агафонов А.Ф. Анализ внутрисортового полиморфизма сортообразцов лука порея методами Rapd- и Issr- анализов. Вестник российской сельскохозяйственной науки. 2015. № 5. С. 53-56.

4. Агафонов А.Ф., Дубова М.В. Селекция лука порея для средней полосы России при выращивании безрассадным способом. Овощи России. 2018. № 3 (41). C. 47-51.

5. Chuda A., Adamus A. Aspects of interspecific hybridization within edible Alliaceae. Acta Physiologiae Plantarum. 2009. № 31. P. 223-227.

6. Адрицкая Н.А., Костко И.Г. Хозяйственно-биологическая и 
технологическая оценка сортов лука-порея в условиях Северо-Западного региона. Известия СПбГАУ. 2016. № 42. URL: https://cyberleninka.ru/article/n/hozyaystvenno-biologicheskaya-itehnologicheskaya- otsenka- sortov- luka- poreya-v- usloviyah- severo-zapadnogoregiona.pdf. (дата звернення: 01.12.2018).

7. Келлер Т.И., Клинг А.П., Сузан В.Г., Коноплев Ю.В., Ворожищев А.В. Оценка продуктивности сортов лука-порея в условиях южной Лесостепи Омской области. Вестник Алтайского государственного аграрного университета. 2015. № 5 (127). С. 26-29.

8. Бобось I. М. Морфологічні особливості сортів цибулі порей в розсадний період. SWorld. 2014. June. P. 17-28. URL: http://www.sworld. com.ua/ index.php/ru/conference/the-content-of-conferences/archives-ofindividual-conferences/june-2014.

9. New Hybrid Leeks. URL: http://vegtrials.blogspot.com/2011/01/newhybrid-leeks.html7th March 2011. (дата звернення: 01.12.2018).

10. Бондаренко Г.Л., Яковенко К.І. Методика дослідної справи в овочівництві і баштанництві. Харків: Основа, 2001. С. 137-145.

11. Ничипорович А.А. Теоретические основы фотосинтетической продуктивности. М.: Наука, 1972. 527 с.

\section{References}

1. Takayeva, Sh.K., Karomatov, I.D. (2017). Medicinal plant leek. Biology and integrative medicine, 2017, no. 5, pp. 232-238 (in Russian).

2. Lubnin, V.F., Loginov, N.A. (2000). Experience growing leek in the Irkutsk region. Gavrish, 2000, no. 1, pp. 13-14 (in Russian).

3. Filyushin, MA, Agafonov, A.F. (2015). Analysis of intravarietal polymorphism of leopard variety samples using Rapd and Issr analyzes. Bulletin of Russian agricultural science, 2015, no. 5, pp. 53-56 (in Russian).

4. Agafonov, A.F. Dubova, M.V. (2018). Breeding of leeks for Central Russia when growing seedlessly. Vegetables of Russia, 2018, no. 3 (41), pp. 47-51 (in Russian).

5. Chuda, A., Adamus, A. (2009). Aspects of interspecific hybridization within edible Alliaceae. Acta Physiologiae Plantarum, 2009, no. 31, pp. 223-227.

6. Adritskaya, N.A., Kostko, I.G. (2016). Economic-biological and technological assessment of varieties of leeks in the North-West region. News SPbGAU, 2016, no. 42. Accessed at https://cyberleninka.ru/article/n/hozyaystvenno-biologicheskaya-itehnologicheskaya - otsenka - sortov - luka - poreya - v - usloviyah - severo- 
zapadnogo - regiona.pdf./ (Accessed December 01, 2018).

7. Keller, T.I., Kling, A.P., Suzan, V.G. et al. (2015). Evaluation of the productivity of varieties of leeks in the southern forest-steppe of the Omsk region. Bulletin of the Altai State Agrarian University, 2015, no. 5 (127), pp. 26-29.

8. Bobosy, I. M. (2014). Morphological features of leeks in seedlings period // SWorld, 2014, June, pp. 17-28. Accessed at https: //www.sworld. com.ua/index.php/en/conference/the-content-of-conferences / archives-ofindividual-conferences / June-2014/ (Accessed December 05, 2017) (in Ukrainian).

9. New Hybrid Leeks. Accessed at http://vegtrials.blogspot.com/2011/01/new-hybrid-leeks.html7th March 2011.

10. Bondarenko, G.L, \&. Yakovenko, K.I. (Eds.). (2001). Research Methodology in case of Vegetables and Melons. Kharkov: Bases, 2001. 234 p. (in Ukrainian).

11. Nichiporovich, A.A. (1972). Theoretical foundations of photosynthetic productivity. M.: Nauka, 1972. 527 pp. (in Russian).

\section{Аннотация}

\section{Слободяник Г.Я., Ульянич Е.И., Тернавский А.Г., Войцеховский В.И.}

Сортовые особенности формирования урожая лука порея в условиях Лесостепи Украины

От сорта зависят сроки поступления и продуктивность выращиваемых овощных растений. Факторами, препятствующими распространению лука порея 8 Украине является неполная реализаиия потенциала урожайности или низкое товарное качество ложного стебля некоторых сортов. Знание закономерностей развития и роста биомассы растений лука порея разных сортов способствует оптимизаиии условий формирования их урожая. Поэтому, на опытных полях Уманского НУС в течении 2016-2018гг. выращивали лук порей сортов Мачек (контроль), Голиас, Колумбус, Веста, Танго, Порбелла и Бартек.

Возможность получения раннего урожая лука порея зависит от диаметра его ложного стебля, который в технической спелости должен быть не менее 0,8-1,5 cм зависимо от разновидности сорта. В течении периода исследований более интенсивное развитие растений большинства сортов порея наблюдали в 2017 г., когда сумма осадков и средняя температура в первой половине вегетаиии порея минимально отличалась от нормыл. В частности, фаза технической спелости ложного стебля сортов Голиас и Танго отмечена через 118-120 суток после всходов. В варианте контроля вегетаиионный период длился 129-136 суток. В сорта болгарской разновидности Веста формирование ложного стебля диаметром 1 см отмечено в среднем на 123 сутки выращивания.

Фотосинтетический потенциал растений всех сортов лука порей сильно связан 
с площуадью листьев. Товарная урожайность также сильно зависит от общего ее уровня - коэффициент корреляции $r=0,82 \pm 0,17$ для сорта Мацек. Самый высокий уровень чистой продуктивности фотосинтеза в растений сорта Веста - 5,96 г/м² в сутки, а площуадь его листьев была только $11,45 \mathrm{mblc.} \mathrm{M}^{2} / 2 а$.

В течении периода исследований сохраняется закономерность максимальной площади листьев, товарной массы и урожайности растений сорта Колумбус -

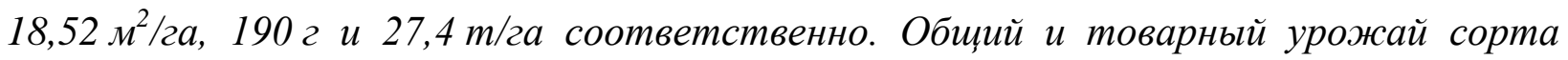
Бартек в среднем был 48,5 m/2a и 24,4 m/2a, что также существенно больше контроля. Достоверно высокий уровень товарного урожая обеспечивает также вырашивание сортов Веста и Голиас с приростом 9,5-10,0 m/2a. В результате проведенной работы сделан вывод о целесообразности выращивания лука порея сортов Колумбус, Веста, Голиас и Бартек.

Ключевые слова: лук порей, сорт, фотосинтетический потенцииал, ложный стебель, урожайность.

\section{Annotation}

\section{Slobodianik H.Ya., Ulianich E.I., Ternavskii A.H., Voitsekhovskii V.I. Varietal features of the leek yield formation in the forest-steppe of Ukraine}

The receipt time and productivity of cultivated vegetable plants depend on the variety. Factors that impede the spread of leek in Ukraine are the incomplete realization of the potential yield or low commercial quality of the sheath of some varieties. Knowledge of the ways the biomass of leek plants of different varieties develops and grows, helps to optimize the conditions for their crop formation. Therefore, on the experimental fields of Uman NUH within the period of 2016-2018 the leek of Matsek (control), Holias, Columbus, Vesta, Tango, Porbella and Bartek varieties were cultivated.

The possibility to obtain an early harvest of leek depends on the diameter of its sheath, which in industrial ripeness should be at least $0.8-1.5 \mathrm{~cm}$, depending on the kind of variety. During the research, more intensive development of plants of most leek varieties was observed in 2017, when the amount of precipitation and the average temperature in the first half of the vegetation period of the leek minimally differed from the norm. In particular, the industrial ripeness phase of the sheath of Golias and Tango varieties is marked 118-120 days after germination. In the control variant, the vegetational season lasted 129-136 days. In the Vesta variety of Bulgarian kind, the formation of a sheath with a diameter of $1 \mathrm{~cm}$ is noted on average in 123 days of cultivation.

The photosynthetic potential of plants of all leek varieties is highly associated with the leaf area. Marketable yield also greatly depends on its overall level - the correlation coefficient $r=0.82 \pm 0.17$ for the Matsek variety. The highest level of photosynthetic net yield in plants of the Vesta variety is $5.96 \mathrm{~g} / \mathrm{m}^{2}$ per day, and the area of its leaves was only 11.45 thousand $\mathrm{m}^{2} / \mathrm{ha}$.

During the research, the regularity of the maximum leaf area, commodity weight and yield of Columbus variety plants is $18.52 \mathrm{~m}^{2} / \mathrm{ha}, 190 \mathrm{~g}$ and $27.4 \mathrm{t} / \mathrm{ha}$, respectively. The total and marketable yield of the Bartek variety was on average 48.5 t/ha and 24.4 t/ha, which is 
also significantly more than control. The significantly high level of marketable yield is also ensured by the cultivation of Vesta and Golias varieties with an increase of 9.5-10.0 t/ha. As a result of this work, it was concluded that the cultivation of Columbus, Vesta, Golias and Bartek leek varieties was expedient.

Key words: leek, variety, potential of photosynthesis, pseudostem, yield.

УДК 631.527:633.63

DOI 10.31395/2415-8240-2019-95-1-157-166

\title{
ВПРОВАДЖЕННЯ ПІДЗИМНІХ ПОСІВІВ БУРЯКУ ЦУКРОВОГО У СЕЛЕКЦЙНИЙ ПРОЦЕС ЗІ СТВОРЕННЯ ЗАПИЛЮВАЧІВ- ЗАКРІПЛЮВАЧІВ СТЕРИЛЬНОСТІ ТА ЇХ АНАЛОГІВ 3 ЦЧС
}

\author{
С. Г. ТРУШ, кандидат сільськогосподарських наук \\ О. О. ПАРФЕНЮК, науковий співробітник \\ Л. О. БАЛАНЮК, науковий співробітник \\ Дослідна станція тютюнництва ННЦ «ІЗ НААН»
}

Доведено ефективність використання підзимніх посівів буряку иукрового в селекиї запилювачів-закріплювачів стерильності та їх аналогів ЦЧС. Встановлено строки сівби і норми висіву насіння, щз забезпечують оптимальний розвиток рослин буряку иукрового восени та їх перезимівлю. Досягнуто прискорення селекційного процесу на один рік, за кожний цикл добору.

Ключові слова: буряк иукровий, гібрид, батьківські компоненти, строк сівби, норма висіву, підзимні посіви, зимостійкість.

Постановка проблеми. Селекція $є$ найрезультативнішим та екологічно чистим фактором зростання виробництва продукції рослинництва. За нинішніх тенденцій підвищення вартості енергозатрат на одиницю виробленої продукції та наявності проблем, що виникли внаслідок загрозливого забруднення навколишнього середовища, селекції відводиться особливо важливе значення.

Значне зростання врожайності сільськогосподарських культур за останні десятиріччя зумовлено насамперед впровадженням у виробництво нових сортів і гібридів [1].

Створення високопродуктивних гібридів буряку цукрового на ЦЧС основі вимагає широких селекційних досліджень 3 їх батьківськими 